\title{
PENGOLAHAN BAHAN PUSTAKA KARYA CETAK DI KANTOR ARSIP DAN PERPUSTAKAAN DAERAH (KAPD)
}

\author{
(Studi Kasus Pengolahan Bahan Pustaka Karya Cetak Pada KAPD Kota Bogor) \\ Ahmad Nurfatah ${ }^{1}$, Ute Lies Siti Khadijah ${ }^{2},{ }^{3}$ Evi Rosfiantika \\ ${ }^{1}$ News Lib. Kompas TV, \\ ${ }^{2,3}$ Program Studi Ilmu Perpustakaan Universitas Padjadjaran \\ 1 $\underline{\text { anurfatah@ymail.com, }}{ }^{2}$ ute.lies@unpad.ac.id, ${ }^{3}$ evi_rosfiantika@yahoo.co.id
}

\begin{abstract}
This study aims to determine the processing operations of library materials in the Regional Office of Archives and Library (KAPD) Bogor in detail, which is based on four main points, namely inventory, classification, cataloging, and shelving. This research was conducted from February until April 2015. The method used is qualitative method with descriptive case study approach to give a deep and detailed overview. The techniques of data collection used are observation, interviews, library and documents research. The results of the survey shows that the inventory is mplemented under the written policy according to the Law of library including assigning and recording the identification numbers, stamping the identity of a library on the book, etc. The books come from APBD, BAPUSIPDA, and PERPUSNAS. The classification mostly done manually by using the DDC book, while the process of entry is done by using the SLIMs program. The making of card catalog has been discontinued since 2010 and OPAC is currently used in exchange. The shelving is conducted based on classification number, notation number, and the code number. The public books are adjusted by the classification numbers and the reference books are adjusted by the code number.
\end{abstract}

Keywords: Processing, library materials, public library

ABSTRAK - Penelitian ini bertujuan untuk menggambarkan proses pengolahan bahan pustaka karya cetak di Kantor Arsip dan Perpustakaan Daerah (KAPD) Kota Bogor, didasarkan pada 4 poin, inventarisasi, klasifikasi, cataloging dan shelving. Penelitian ini dilaksanakan pada Februari hingga April 2015. Metode yang digunakan ialah metode kualitatif melalui deskriptif, pendekatan studi kasusu untuk memberikan pendalaman dan rinci. Teknik pengumpulan data yang digunakan adalah observasi, wawancara, studi literatur dan dokumen. Hasil penelitian menunjukkan bahwa implementasi kebijakan perundang-undangan tertulis termasuk menugaskan dan merekam nomor dan pelabelan identitas buku perpustakaan. Buku-buku tersebut berasal dari APBD, BAPUSIPDA, dan PERPUSNAS. Klasifikasi sebagian besar digunakan secara manual melalui buku DDC, lalu menggunakan program SLIM setelah kegiatan entri selesai. Pembuatan kartu katalog telah dihentikan sejak 2010 dan saat ini menggunakan OPAC dalam pertukaran rak yang dilakukan berdasarkan nomor klasifikasi, jumlah notasi dan nomor kode. Buku-buku umum disesuaikan dengan nomor klasifikasi dan buku referensi disesuaikan dengan jumlah kode.

Kata kunci: Pengolahan, bahan perpustakaan, perpustakaan umum

\section{PENDAHULUAN}

Kondisi pengolahan di KAPD Kota Bogor sudah tidak menerapkan pembuatan kartu katalog. Hal tersebut karena KAPD Kota Bogor sudah mengandalkan penggunaan sistem OPAC (Online Pubic Access Catalogue) sebagai media untuk memudahkan para pustakawan maupun pengguna perpustakaan. Kegiatan inventarisasi koleksi bahan pustaka pun masih dilakukan secara manual oleh pustakawan dan staf perpustakaan tersebut.

Pengolahan di KAPD Kota Bogor umumnya menerapkan sistem klasifikasi sederhana yang kebanyakan menggunakan kelas utama dan sub kelas. Keadaan perpustakaan di KAPD Kota 
Bogor memiliki keterbatasaan ruangan, sedangkan koleksi bahan pustaka yang terdapat pada perpustakaan tersebut berjumlah cukup banyak. Bahan pustaka yang didatangkan ditentukan oleh dana yang tersedia, namun KAPD Kota Bogor dalam setiap tahunnya menerima koleksi bahan pustaka berupa buku sebanyak 3.000 eksemplar yang diberi oleh Perpusnas dan lembaga-lembaga lainnya. Banyaknya jumlah buku yang diberikan dapat disimpulkan bahwa bahan pustaka terutama bejenis buku masih memiliki tingkat pertumbuhan yang cepat dan pesat. Kantor Arsip dan Perpustakaan Daerah (KAPD) Kota Bogor merupakan jenis perpustakaan umum dan termasuk ke dalam lembaga perpustakaan yang cukup besar di kota Bogor. Perpustakaan tersebut dinaungi oleh pemerintah daerah dan termasuk ke dalam naungan Perpustakaan Nasional (Perpusnas) Republik Indonesia.

Perpustakaan merupakan lembaga untuk memenuhi kebutuhan seluruh lapisan masyarakat dalam menyediakan informasi sebagai fasilitas media pembelajaran dalam menambah wawasan masyarakat. Oleh karena itu, perlu adanya sistem pengolahan yang sesuai dengan aturan dan ketetapan kebijakan pada perpustakaan tersebut.

Sesuai papara di atas, penelitian memiliki fokus penelitian pada proses pengolahan bahan pustaka karya cetak di Kantor Arsip dan Perpustakaan Daerah (KAPD) Kota Bogor. Hasil penelitian ini untuk mengetahui:

1. Bagaimana proses inventarisasi koleksi bahan pustaka karya cetak di KAPD Kota Bogor?
2. Bagaimana proses klasifikasi koleksi bahan pustaka karya cetak di KAPD Kota Bogor?

3. Bagaimana proses katalogisasi koleksi bahan pustaka karya cetak di KAPD Kota Bogor?

4. Bagaimana proses shelving koleksi bahan pustaka karya cetak di KAPD Kota Bogor?

\section{TINJAUAN PUSTAKA}

Pengolahan koleksi di perpustakaan dimulai dari pemeriksaan koleksi yang baru datang sampai koleksi tersebut siap disajikan dan disusun di rak guna dimanfaatkan oleh penggunanya (Yusuf \& Suhendar, 2010). Pengolahan koleksi merupakan proses penyiapan koleksi untuk dapat dilayankan kepada pengguna.

Dalam pengolahan buku di perpustakaan ada beberapa langkah yaitu sebagai berikut (Rahayuningsih, 2007):

a. Inventarisasi, yakni mendaftar koleksi yang baru datang berupa pemberian stempel buku dan pemberian nomor buku. Pemberian stempel buku yakni pembubuhan stempel buku yang sudah masuk di perpustakaan di balik halaman judul, bagian tengah halaman, bagian yang tidak ada tulisan atau gambar, pada halaman akhir, dan pada halaman yang dianggap rahasia, tergantung kebijakan yang berlaku di perpustakaan tersebut. Sedangkan pemberian nomor buku berdasarkan klasifikasi (call number). Nomor induk adalah nomor urut buku 
yang sudah ada dari nomor satu sampai nomor terakhir menunjukkan nomor buku klasifikasi

b. Klasifikasi adalah penggolongan atau pengelompokkan buku berdasarkan subjek atau isi buku yang bersangkutan. Ada beberapa macam sistem klasifikasi yang digunakan oleh perpustakaan di dunia, seperti Dewey Decimal Classification (DDC), Universal Decimal Classification (UDC), Library of Congress Classification (LCC), Colon Classification (CC), dan lain-lain. Sistem klasifikasi yang paling banyak digunakan di beberapa negara di dunia termasuk negara Indonesia yaitu Dewey Decimal Clasification (DDC)

c. Katalogisasi, terdiri dari deskripsi bibliografi, penentuan tajuk subjek, dan klasifikasi

d. Penjajaran kartu (file), kartu katalog yang sudah selesai dibuat kemudian dijajarkan pada laci catalog. Penjajaran kartu ini dijajarkan menurut abjad (alfabetis)

e. Penyusunan koleksi (buku) di rak, terdapat dua cara, yaitu penempatan yang tetap (fix locations), artinya jika sudah ditempatkan di situ tidak bisa dipindahkan lagi. Jika ada penambahan koleksi, maka ditempatkan di rak lain dan penempatan relative atau tidak tetap (relative locations), artinya penempatan koleksi dapat berubah atau berpindah karena koleksi yang subjeknya sama arus terkumpul daam satu tempat.

\section{METODE PENELITIAN}

Metode penelitian yang digunakan dalam penelitian ini adalah studi kasus. Studi kasus merupakan metode penelitian ilmu-ilmu sosial. Studi kasus dibagi menjadi tiga tipe, yaitu studi kasus eksplanatoris, eksploratoris, dan deskriptif (Moleong, 2008). Dalam penelitian ini, tipe studi kasus yang digunakan oleh peneliti adalah studi kasus deskriptif (Yin, 2006).

Pada penelitian ini peneliti menggunakan metode kualitatif dengan pendekatan studi kasus deskriptif yang bertujuan untuk memberikan gambaran yang mendalam secara detail mengenai Pelaksanaan Pengolahan Bahan Pustaka di Kantor Arsip dan Perpustakaan Daerah (KAPD) Kota Bogor. Pengumpulan data yang dilakukan yaitu dengan observasi, wawancara yang jumlah narasumbernya terdapat empat orang, Eddy selaku ketua urusan pengolahan, Gita selaku pustakawan, Tita selaku ketua KAPD Kota Bogor, dan Pawit selaku ketua prodi Departemen Ilmu Informasi dan Perpustakaan Fikom Unpad. Serta pengumpulan data dilakukan dengan studi pustaka. Tempat yang dijadikan objek penelitian ini dilaksanakan di Kantor Arsip dan Perpustakaan Daerah (KAPD) Kota Bogor, dilakukan pada awal bulan Januari 2015 hingga akhir bulan Februari 2015.

\section{HASIL DAN PEMBAHASAN}

Pada Kantor Arsip dan Perpustakaan Daerah (KAPD) Kota Bogor terdapat tiga bagian aspek 
pengelolaan yang diterapkan, diantaranya yaitu pengadaan, pengelolaan, dan pelayanan. Setiap aspek tersebut telah disediakan ruang kerja masing-masing oleh pihak KAPD Kota Bogor. Oleh karena itu, pada penelitian ini peneliti menjadikan kegiatan pengolahan dari tiga aspek pengelolaan pada perpustakaan sebagai objek penelitian.

Proses inventarisasi bahan pustaka KAPD Kota Bogor masih menerapkan sistem manual yang menggunakan tenaga kerja staf pustakawan, dengan demikian pihak tenaga kerja di kantor tersebut cukup kewalahan dalam melakukan kegiatan inventarisasi. Namun faktor tersebut tidak membuat proses kegiatan inventarisasi terhambat ataupun terhenti.

Sama halnya dengan kegiatan inventarisasi, proses kegiatan klasifikasi bahan pustaka yang dilakukan di KAPD Kota Bogor pada umumnya menerapkan sistem klasifikasi sederhana yang kebanyakan menggunakan kelas utama dan sub kelas. Kegiatan katalogisasi dalam beberapa bulan lalu masih menerapkan dan membuat kartu katalog, namun seiring perkembangan dan kemunculan teknologi yang semakin canggih membuat kegiatan katalogisasi beralih menggukan sistem OPAC (Online Public Access Catalogue).

Kegiatan shelving yang diterapkan oleh KAPD Kota Bogor dilakukan secara sistematis dan teratur. Proses shelving mulai dilakukan menunggu koordinasi dari pihak bagian pelayanan. Hal tersebut dikarenakan agar menghindari kejadian koleksi yang menumpuk di ruang koleksi bahan pustaka, khususnya di ruang koleksi karya umum. Penerapan kegiatan inventarisasi di KAPD Kota Bogor mengacu berdasarkan ketetapan yang telah disesuaikan oleh pihak perpustakaan tersebut.dalam melakukan proses inventarisasi, KAPD Kota Bogor menggunakan Undang-Undang perpustakaan sebagai acuan dalam kebijakan pada proses tahapan kegiatan tersebut.

Sebagian besar berasal dari pembelian yang dilakukan oleh KAPD Kota Bogor melalui dana yang diberikan oleh Anggaran Pendapatan dan Belanja Daerah (APBD). Selain itu dapat bantuan dari dana pemerintah, propinsi, terutama bantuan yang diterima dari Badan Perpustakaan dan Arsip Daerah (BAPUSIPDA) dan bantuan dari Perpustakaan Nasional (PERPUSNAS). KAPD Kota Bogor dilakukan terlebih dahulu proses tahapan penyeleksian dan pengelompokkan atas dasar bahan pustaka berjenis fiksi dan nonfiksi. Kemudian setelah tahapan tersebut diselesaikan, maka akan dilakukan proses inventarisasi berupa proses pencatatan identitas bahan pustaka kedalam buku induk meliputi judul buku, pengarang buku, nomor induk, perolehan atau asal buku, nomor klasifikasi, dan keterangan.

Proses selanjutnya pada tahapan inventarisasi yaitu pemberian cap perpustakaan dan pemberian cap inventaris pada setiap buku. Pada kegiatan klasifikasi di KAPD Kota Bogor melakukan klasifikasi sesuai dengan prosedur yang sudah ditetapkan. Bahan pustaka yang telah diinventarisasi secara manual langsung diolah melalui otomasi perpustakaan. Dengan adanya otomasi yang tersedia pada perpustakaan, maka pengisian entri data bahan pustaka pada komputer 
tidak rumit menggunakan SLIMs. Proses tahapan klasifikasi di KAPD Kota Bogor dilihat dari subjeknya, lalu setelah nomor kelas sudah tepat yang mengacu dari DDC dengan subjek buku tersebut, kemudian dimasukkan dan dicatat nomor klasifikasinya. Proses klasifikasi pun dapat dilakukan dengan mengacu pada delapan daerah atau deskripsi bibliografi, seperti pengarang buku, judul buku, penerbit, subjek buku, deskripsi fisik, ISBN, nomor induk, nomor klasifikasi, tahun terbit. Karena hal tersebut telah tersedia dalam SLIMs.

KAPD Kota Bogor merupakan perpustakaan umum, perpustakaan tersebut menggunakan sistem klasifikasi DDC sebagai acuan untuk menentukan nomor kelas pengelompokan bahan pustaka. Alasan pihak KAPD Kota Bogor menggunakan DDC sebagai acuan ialah karena hal tersebut selama ini pihak KAPD Kota Bogor mendapat pembinaan dari pihak perpustakaan propinsi, oleh karena itu dianjurkan untuk diseragamkan dalam menggunakan DDC sebagai sistem klasifikasi. Rumitnya kegiatan klasifikasi menghasilkan kendala, faktor yang menjadi kendala di KAPD Kota Bogor ialah jumlah SDM yang tersedia di bagian pengolahan cukup minim. Pustakawan yang menangani bagian pengolahan hanya dua orang, dan tiga orang lainnya hanya staf biasa yang tidak memiliki keilmuan dalam bidang perpustakaan.

Proses pembuatan kartu katalog di KAPD Kota Bogor sudah tidak dilakukan lagi sejak beberapa tahun belakangan, terakhir kali dibuat pada tahun 2010 yang lalu. Saat ini KAPD Kota Bogor telah menggunakan sistem otomasi perpustakaan yang berlaku, sehingga telah tersedianya SLIMs dan OPAC. Walaupun perpustakaan KAPD Kota Bogor sudah menggunakan OPAC namun tetap saja terdapat faktor yang menjadi kendalanya, biasanya kendala yang terjadi yaitu listrik padam. Hal itu membuat proses pengisian di OPAC juga terhambat dan membuat pengunjung kesulitan saat mencari buku yang dibutuhkan menjadi kesulitan.

Tahapan shelving ialah tahapan terakhir yang terdapat pada kegiatan pengolahan di perpustakaan. Pada KAPD Kota Bogor sebelum melakukan proses shelving terlebih dahulu melakukan proses pencetakan dan penempelan nomor panggil serta barkod buku. Untuk penempelan nomor panggil diletakkan dibagian punggung buku dan penempelan barkod buku diletakkan dibagian cover belakang buku, hal tersebut sesuai dengan ketentuan dari KAPD Kota Bogor. Proses shelving yang dilakukan oleh KAPD Kota Bogor didasarkan pada nomor klasifikasi, ketetapan yang cukup sederhana dalam menata dan menyusun koleksi buku. Buku- buku yang telah diolah dan ditempelkan nomor panggil atau nomor klasifikasi dikumpulkan terlebih dahulu, lalu ditempatkan dan dicocokan sesuai antara nomor klasifikasi pada buku dan nomor kelas pada rak buku.

Seluruh buku ditata dengan rapi, dikelompokkan sesuai dengan jenis buku tertentu. Jadi buku berjenis karya umum disatukan dengan jenis karya umum lainnya, sedangkan buku berjenis referensi disatukan dengan jenis referensi lainnya. Terdapat faktor kendala yang dianggap 
cukup serius bagi pihak KAPD Kota Bogor. Jumlah bahan pustaka yang sangat banyak tersedia dan penerimaan buku yang datang di KAPD Kota Bogor menjadi hambatan karena posisi ruangan yang kecil membuat pihak perpustakaan bingung untuk menampung dan meletakkan banyaknya buku-buku yang telah diolah tersebut.

\section{SIMPULAN}

Berdasarkan paparan di atas, maka hasil penelitian ini dapat disimpulkan sebagai berikut:

1. Kegiatan inventarisi di KAPD Kota Bogor telah memiliki kebijakan tertulis yang telah ditentukan sesuai dengan undang-undang perpustakaan yang berlaku. Jadi KAPD Kota Bogor menjadikan kebijakan tersebut sebagai acuan di dalam melakukan kegiatan inventarisasi

2. Bahan pustaka yang diterima oleh pihak KAPD Kota Bogor berasal dari pembelian yang anggarannya berasal dari APBD, bantuan sumbangan dari pihak propinsi, dan bantuan sumbangan dari masyarakat. Walaupun KAPD Kota Bogor adalah perpustakaan umum dibawah naungan PEMDA, namun masih melakukan proses inventarisasi secara manual seperti pencatatan data buku $\mathrm{k}$ dalam buku induk, pemberian cap pada buku dan lain sebagainya. Kendala pada proses ini terdapat pada jumlah SDM yang tersedia, hal tersebut terkadang menghambat proses kinerja saat melakukan inventarisasi, terlebih lagi proses tersebut masih melakukannya secara manual, namun masih dapat terbantu jika sedang adanya pelajar siswa maupun mahasiswa yang melakukan Praktek Kerja Lapangan. Jadi KAPD Kota Bogor setiap jangka waktu dalam satu tahun dapat menyelesaikan 1500 hingga 2000 jumlah buku

3. Pada proses klasifikasi, di KAPD Kota Bogor dalam penentuan nomor panggil klasifikasi masih dilakukan secara manual. Jenis sistem klasifikasi yang digunakan ialah DDC, buku DDC edisi ke-23 juga masih digunakan dalam pencarian dan penentuan nomor panggil klasifikasi. Namun penggunaan otomasi atau digitalisasi perpustakaan sudah digunakan hanya di dalam melakukan pengentrian data buku melalui SLIMs. Jenis sistem yang diterapkan dengan menggunakan DDC disebut sebagai sistem yang sederhana dan mudah, KAPD Kota Bogor pun mendapat pembinaan dari pihak perpustakaan propinsi dalam penerapan sistem tersebut. Sama seperti tahapan sebelumnya, pada tahapan klasifikasi ini kendala yang dialami yaitu kurangnya SDM yang bekerja. Pekerja yang memiliki dan menguasi ilmu di bidang ilmu perpustakaan sangat sedikit. Hal tersebut menjadikan pihak KAPD Kota Bogor kesulitan dalam menyelesaikan proses klasifikasi dengan 
cepat, karena tugas para pekerja di bagian pengolahan tidak hanya mengerjakan proses pengolahan bahan pustaka saja. Akan tetapi tidak selalu mengalami kesulitan, hal tersebut karena sudah cukup banyak buku-buku yang terdapat KDT (Katalog Dalam Terbitan), jadi para pustakawan tidak perlu mencari nomor klasifikasi pada buku DDC secara manual

4. Pada proses katalogisasi, di KAPD Kota Bogor sudah tidak menggunakan dan membuat kartu katalog. Kegiatan tersebut terakhir kali dilakukan pada periode tahun 2003 hingga 2010. Karena saat ini dengan pesatnya teknologi canggih maka sudah beralih pada SLIMs dan OPAC. Namun terlepas dari pembuatan kartu katalog, pihak KAPD Kota Bogor tetap menyimpan kartu katalog tersebut. Berdasarkan hasil penelitian bahwa ketika proses pembuatan kartu katalog masih diberlakukan, KAPD Kota Bogor menerapkannya sesuai dengan standar ilmu perpustakaan. Biarpun sudah mengandalkan sistem OPAC dan SLIMs tetap mengalami kendala dan hambatan, kendala yang dialami ialah padamnya tenaga listrik sehingga menghambat di dalam proses pemasukan data kedalam OPAC dan menghambat pencarian buku ketika pengunjung yang hendak meminjam
5. Pada proses shelving, kegiatan terlebih dahulu sebelum dilakukannya tahapan shelving ialah pencetakan dan penempelan nomor panggil dan barkod pada buku. Lalu proses shelving yang dilakukan di KAPD Kota Bogor pada buku berjenis karya umum mengacu berdasarkan pada nomor klasifikasi secara teratur dan dicocokkan dengan nomor klasifikasi yang disediakan di setiap rak-rak buku. Sedangkan untuk buku-buku referensi ditata berdasarkan nomor kode pada buku yang ditempatkan di rak sesuai nomor notasi. Proses kegiatan shelving yang diterapkan oleh KAPD Kota Bogor sesuai dengan kesepatakan dan kebijakan yang sudah dibuat menurut lembaga perpustakaan tersebut. Pada proses shelving ini terdapat kendala yang cukup membuat pihak KAPD Kota Bogor kesulitan untuk mencari solusinya. Dengan banyaknya jumlah buku yang diolah hingga siap disajikan dengan melakukan shelving, kendala yang terdapat pada perpustakaan tersebut ialah terbatasnya luas tata ruangan yang tersedia, hal tersebut dikarenakan gedung perpustakaan yang tidak terlalu besar dan pemasukan jumlah buku yang terus menerus mengalami pembaharuan. Biar pun terdapat kendala juga pada jumlah rak yang tersedia, namun kendala tersebut cukup dapat diatasi. 


\section{DAFTAR PUSTAKA}

Moleong, L. J. (2008). Metodologi Penelitian Kualitatif. Bandung: Remaja Rosdakarya. Rahayuningsih, F. (2007). Pengelolaan

Perpustakaan. Yogyakarta: Graha Ilmu.
Yin, R. K. (2006). Studi Kasus Desain dan Metode. Jakarta: Rajawali Pers.

Yusuf, P. M., \& Suhendar, Y. (2010). Pedoman Penyelenggaraan Perpustakaan Sekolah. Jakarta: Kencana Prenada Media Group. 